\title{
Accumulation and transport of seagrass-derived organic matter in reef flat sediment of Green Island, Great Barrier Reef
}

\author{
Toshihiro Miyajima $^{1, *}$, Isao Koike ${ }^{1}$, Hiroya Yamano ${ }^{2}$, Hitoshi Iizumi ${ }^{3}$ \\ ${ }^{1}$ Marine Biochemistry Laboratory, Ocean Research Institute, The University of Tokyo, Nakano, Tokyo 164, Japan \\ ${ }^{2}$ Department of Geography, Faculty of Science, The University of Tokyo, Hongo, Tokyo 113, Japan \\ ${ }^{3}$ Hokkaido National Fishery Research Institute, Kushiro, Hokkaido 085, Japan
}

\begin{abstract}
Coral-reef sediment vegetated by seagrasses is usually enriched in organic matter as compared with unvegetated reef sediment. This study focused on comparisons of sediment composition and mobility between vegetated and unvegetated sediments of Green Island reef (the Great Barrier Reef, Australia). Seagrass-derived macroscopic debris and amorphous detrital organic matter were especially responsible for the organic enrichment in the seagrass-bed sediment, while carbonate-associated, acid-soluble organic matter was only slightly enriched in seagrass beds. A sediment-trap experiment revealed that particles trapped in the seagrass beds were richer in organic carbon than those collected in the unvegetated area, although the organic carbon flux depended on wind condition rather than vegetation. The trapped organic particles had $C: N: P$ ratios similar to the amorphous organic fraction of sediment organic matter, being significantly enriched in $\mathrm{N}$ and $\mathrm{P}$ as compared with seagrassderived, macroscopic organic fragments. Conservation of $\mathrm{N}$ and $\mathrm{P}$ during bacterial decomposition of plant-derived organic matter is probably responsible for the enrichment of $\mathrm{N}$ and $\mathrm{P}$. The characteristic time scale of the amorphous organic matter turnover by resuspension and deposition was estimated to be tens of days or less, being comparable to or faster than mineralization. These comparisons suggest that seagrass beds effectively enhance sedimentary storage of organic $C$, $N$ and $P$, with the turnover of the organic pools being controlled by physical processes as well as by mineralization.
\end{abstract}

KEY WORDS: Seagrass beds · Nutrient dynamics - Organic carbon - Nitrogen P Phosphorus Sediment trap Turnover

\section{INTRODUCTION}

Seagrass beds are widespread over the littoral regions of tropical Pacific and often occur on reef flats and lagoons of fringing and barrier reefs (Mukai 1993). Coverage with seagrass vegetation modifies the organic carbon storage in reef-flat sediments (Morse et al. 1987, Moriarty \& Boon 1989). Mechanisms by which seagrass beds modify the organic carbon content in sediment have been postulated: (1) direct supply of organic matter to sediment in the form of rhizomes, fine roots, leaf fragments, and organic exudate from

•E-mail: miyajima@ori.u-tokyo.ac.jp the roots (Klug 1980, Yamamuro et al. 1993), (2) selective dissolution of the inorganic (carbonate) fraction of sediment through interaction with respired $\mathrm{CO}_{2}$ from the roots (Tribble et al. 1990), (3) entrapment and enhancement of sedimentation of suspended organic matter from overlying sea water by the seagrass leaves (Scoffin 1970, Ward et al. 1984, Almasi et al. 1987), and (4) stabilization against erosion of organically rich sediment surface due to wave energy reduction by the leaf blades and sediment binding by the root system (Wanless 1981, Fonseca \& Fisher 1986, Fonseca 1989, Fonseca \& Cahalan 1992). However, since seagrasses may be equally as effective for entrapment and stabilization of inorganic sediment particles as of organic sediment particles, it may be questioned whether the physical 
modification of deposition environments (i.e. postulations [3] and [4] above) really causes organic enrichment of sediment. So far, there are only a few studies which have addressed the effect of the seagrass bed on the chemical composition of entrapped or resuspended sediment materials. A recent study by Dauby et al. (1995) on a Mediterranean seagrass bed showed that seagrass-derived detritus was resuspended and significantly contributed to the total particle flux over the seagrass bed. Thus, resuspension, migration and resettlement of seagrass-derived organic matter may control the horizontal distribution of organic carbon in sediment.

Increase of organic carbon content in the sediment can also affect cycling of other biophilic elements such as nitrogen and phosphorus. Nitrogen and phosphorus can be stored in the sediment in particulate organic form and as pore-water nutrients. In reef-flat ecosystems where the exchange of water is rapid, the turnover time of $\mathrm{C}, \mathrm{N}$ and $\mathrm{P}$ in the sediment is often several orders of magnitude longer than in the water column (Hatcher et al. 1987). Hence, by storing large pools of nitrogen and phosphorus in the sediment, seagrass beds may significantly alter the time scale of nutrient cycling.

In this study, we compared chemical composition of sediment, seagrass-derived detritus, suspended organic matter, and trapped sinking particles between

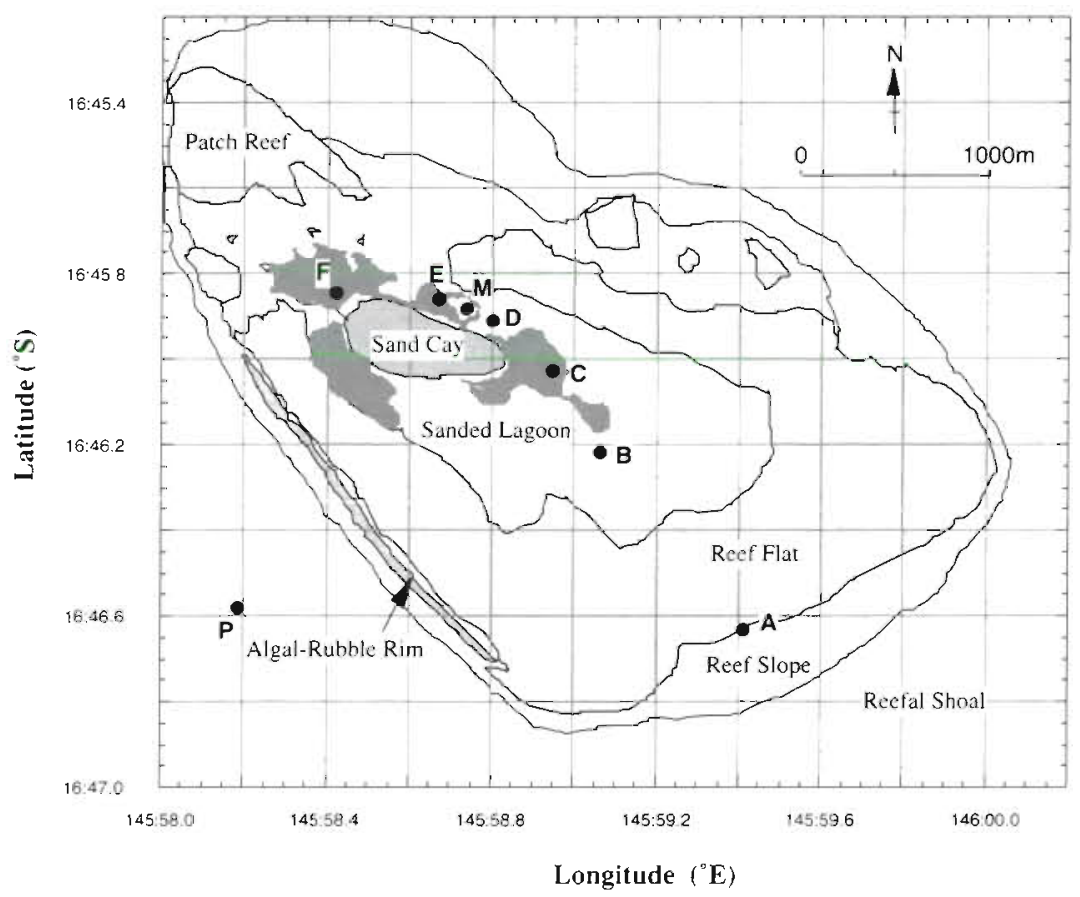

Fig. 1. Geomorphological map of Green Island (Great Barrier Reef, Australia) with sampling stations. Dark-shaded zones around the sand cay are seagrass beds seagrass beds and adjacent unvegetated area on the reef flat of Green Island (the Great Barrier Reef) to evaluate the effects of the seagrass beds on transport and distribution of sediment organic matter. We analyzed sediment organic matter after partitioning it into acid-soluble and acid-insoluble fractions, in order to tentatively distinguish plant-derived detritus from organic matrix originally associated with biogenic carbonate minerals, and compared $\mathrm{C}: \mathrm{N}$ and $\mathrm{C}: \mathrm{P}$ ratios to characterize organic matter.

\section{MATERIALS AND METHODS}

Study site. This study was conducted in a reef system around a sand cay, Green Island $\left(16^{\circ} 45^{\prime}-16^{\circ} 47^{\prime} \mathrm{S}\right.$, $145^{\circ} 58^{\prime}-146^{\circ} 00^{\prime}$ E, Fig. 1), in the Great Barrier Reef, NE Australia, in October 1996. Air temperature in this month ranged from 21 to $28^{\circ} \mathrm{C}$. SSE to ESE wind prevailed during the study period, with wind speed of 5 to $14 \mathrm{~m} \mathrm{~s}^{-1}$ (Green Island Automatic Weather Station). Six sampling stations $(\mathrm{A}-\mathrm{F})$ were set along a water stream contour that flowed into the reef flat at the south east edge, passed along the north edge of the sand cay, and left off the north west edge of the cay. Stns C, E and F were located in seagrass beds, while Stns $A, B$ and D were in unvegetated areas. An additional station, Stn $M$, was in a small gap in the seagrass meadow near Stn E. For seawater analysis, an additional water sample was collected at the outside of the reef area ( $\operatorname{Stn} P$ ). The upstream stations $\mathrm{A}, \mathrm{B}$ and $\mathrm{C}$ were almost exposed at the low spring tide (water depth 10 to $50 \mathrm{~cm}$ with some microatolls being emerged), while at Stns D, E, F and $M$, the sediment surface was 1 to $3 \mathrm{~m}$ below the lowest water level at spring tide. Common seagrass species were Thalassia hemprichii and Cymodocea serrulata at Stn $C$, and C. serrulata, Syringodium isoetifolium and Halodule uninervis at Stns E and F. Detailed hydrographic conditions of the study site are described elsewhere (Yamano et al. unpubl.).

Core and water samples. Sediment cores (10 to $20 \mathrm{~cm}$ long) were sampled using transparent acrylic plastic cylinders $(5 \mathrm{~cm}$ inner diameter and $30 \mathrm{~cm}$ length). At Stns $A, B$ and $C$, the cores were sampled during low tide, whereas at the other stations the cores were obtained by SCUBA divers. Duplicate cores were sampled at each station. At 
the same time, overlying sea water just above the sediment surface was sampled into $10 \mathrm{ml}$ acrylic plastic tubes. Surface sea water was also sampled by a $5 \mathrm{l}$ Van-Dorn sampler during high tide from a boat into $10 \mathrm{ml}$ acrylic tubes (for nutrient analysis) and $10 \mathrm{l}$ polypropylene bottles (for particulate malter analysis). The water samples in the $10 \mathrm{ml}$ tubes were stored at $-20^{\circ} \mathrm{C}$ From surface water in the $10 \mathrm{l}$ bottles, $100 \mathrm{ml}$ was filtered through a glass fiber filter (Whatman, GF/F, $25 \mathrm{~mm}$ diameter) to collect particulate matter for chlorophyll analysis, $400 \mathrm{ml}$ was filtered through a preignited, acid-soaked $47 \mathrm{~mm}$ GF/F filter for particulate phosphorus analysis, and 3 to $6 \mathrm{l}$ was filtered through a pre-ignited $47 \mathrm{~mm}$ GF/F filter for particulate carbon and nitrogen analysis. Filters for chlorophyll analysis were immediately soaked in $\mathrm{N}, \mathrm{N}$-dimethylformamide (DMF, $6 \mathrm{ml}$ ) to extract pigments and stored at $-20^{\circ} \mathrm{C}$ until fluorometric analysis. Filter samples for particulate organic matter (POM) were frozen for transportation.

Sediment cores were cut into 2 to $4 \mathrm{~cm}$ horizontal sections using a stainless-steel spatula. Approximately $50 \mathrm{mg}$ of the top-layer sediments was transferred into DMF $(6 \mathrm{ml})$ to extract chlorophylls. Each section was packed in a polyethylene bag and weighed, then $10 \mathrm{ml}$ of $\mathrm{GF} / \mathrm{F}$ filtered, low-nutrient sea water lobtained at Stn P) was added to the bag. After homogenization by hand-shaking, the aqueous fraction in the bag was filtered through a pre-ignited glass fiber filter. The filter with trapped material was returned to the bag that contained the rest of the sediment sample, and the bag was frozen at $-20^{\circ} \mathrm{C}$ for transportation. The filtrate was transferred to a $10 \mathrm{ml}$ acrylic tube and frozen. The bags were later put in a vacuum oven $\left(50^{\circ} \mathrm{C}\right)$, with the contents exposed, to dry to constant weight, and weighed again to calculate water content of the sediments. Macroscopic plant material (live and dead rhizomes, fine roots, large leaf debris) was picked out by forceps and weighed. Plant material and the remainder of the dried sediments were used to analyze for carbon, nitrogen and phosphorus content.

Sediment trap experiment. Triplicate wide-mouthed glass bottles of $13.9 \mathrm{~cm}^{2}$ exposed cross-sectional area and $10 \mathrm{~cm}$ height, tied to a peg of ca $30 \mathrm{~cm}$ length, were used as sediment traps. The experiment was conducted 4 times at 6 stations (A-F). The bottles were at first filled with surface sea water, then covered with screw caps, and placed directly on the sediment surface. After sediment particles resuspended by trap placement had settled again or flowed away, the caps of the bottles were carefully removed. Traps were exposed for about $24 \mathrm{~h}$. The content of retrieved traps was filtered through a GF/F filter to retain the trapped particles on the filter. The filter was then dried in a vacuum oven $\left(50^{\circ} \mathrm{C}\right)$ and weighed. Part of the trapped material was subjected to analyses for organic carbon, nitrogen and phosphorus content.

Chemical analyses. Nutrient concentrations $\left(\mathrm{NO}_{3}{ }^{-}\right.$, $\mathrm{NO}_{2}{ }^{-}, \mathrm{NH}_{4}{ }^{+}$, reactive phosphate) were determined by an autoanalyzer (Technicon, AutoAnalyzer-IITM). For pore-water analysis, nutrient concentrations were calculated accounting for porosity of the sediment and carry-over from the sea water used for pore water extraction. Total dissolved nitrogen and phosphorus were determined as $\mathrm{NO}_{3}{ }^{-}$and $\mathrm{PO}_{4}{ }^{3-}$ after oxidation by $\mathrm{K}_{2} \mathrm{~S}_{2} \mathrm{O}_{8}$ solution (Grasshoff 1976), from which inorganic nitrogen and phosphorus concentrations were subtracted to obtain dissolved organic nitrogen and phosphorus concentrations, respectively. For determination of particulate organic carbon and nitrogen, the filters on which suspended particulate matter was collected were dried at $50^{\circ} \mathrm{C}$, treated with $\mathrm{HCl}$ vapor overnight to remove carbonate, dried again in vacuo, and analyzed by a CHN analyzer (Fisons, NA-1500). For particulate phosphorus, the filters were treated with $5 \%$ $\mathrm{K}_{2} \mathrm{~S}_{2} \mathrm{O}_{8}$ solution at $121^{\circ} \mathrm{C}$ for $1 \mathrm{~h}$, and the supernatant was analyzed for reactive phosphorus. Unused acidwashed filters were similarly treated to estimate the filter blank. Chlorophyll a concentration was determined on the DMF extracts by a fluorometer (Turner Design).

To determine organic carbon and nitrogen contents in the sediment samples, $1.00 \mathrm{~g}$ of dried sediment was soaked in $5.00 \mathrm{ml}$ of $4.2 \mathrm{~N} \mathrm{HCl}$ solution to dissolve carbonate. The solution was well homogenized, and an appropriate portion was passed through a preignited glass fiber filter. The filter was washed with $1 \mathrm{ml}$ of distilled water, dried at $40^{\circ} \mathrm{C}$ and analyzed by the CHN analyzer. The values obtained were regarded as the $\mathrm{C}$ and $\mathrm{N}$ in the acid-insoluble, amorphous organic fraction of the sediment (referred to as Fraction-I). Another pre-ignited GF/D filter (10 mm) was spotted with the filtrate $(400 \mu \mathrm{l})$ of the above solution, dried at $40^{\circ} \mathrm{C}$ and analyzed by the CHN analyzer. This was regarded as the acid-soluble organic fraction of sediment (Fraction-S). Organic C and $N$ contents of sediment-trap samples and plant debris picked out of the sediment (referred to as Fraction-D) were determined by the vapor acidification method of Hedges \& Stern (1984), which was slightly modified as follows. The sample was crushed into powder, and a 10 to $50 \mathrm{mg}$ portion was transferred into a small silver container which had been soaked in pure ethanol overnight and dried well. The container was kept in an air-tight container with concentrated $\mathrm{HCl}$ for $3 \mathrm{~d}$. A drop of $0.1 \mathrm{~N} \mathrm{HCl}$ was added to confirm complete removal of carbonate, then the containers were dried at $40^{\circ} \mathrm{C}$ and analyzed by the CHN analyzer.

Phosphorus in the sediment samples was fractionated and analyzed as follows. A total of $500 \mathrm{mg}$ of sample was soaked in $10.0 \mathrm{ml}$ of $1.2 \mathrm{~N} \mathrm{HCl}$ solution for $24 \mathrm{~h}$ 

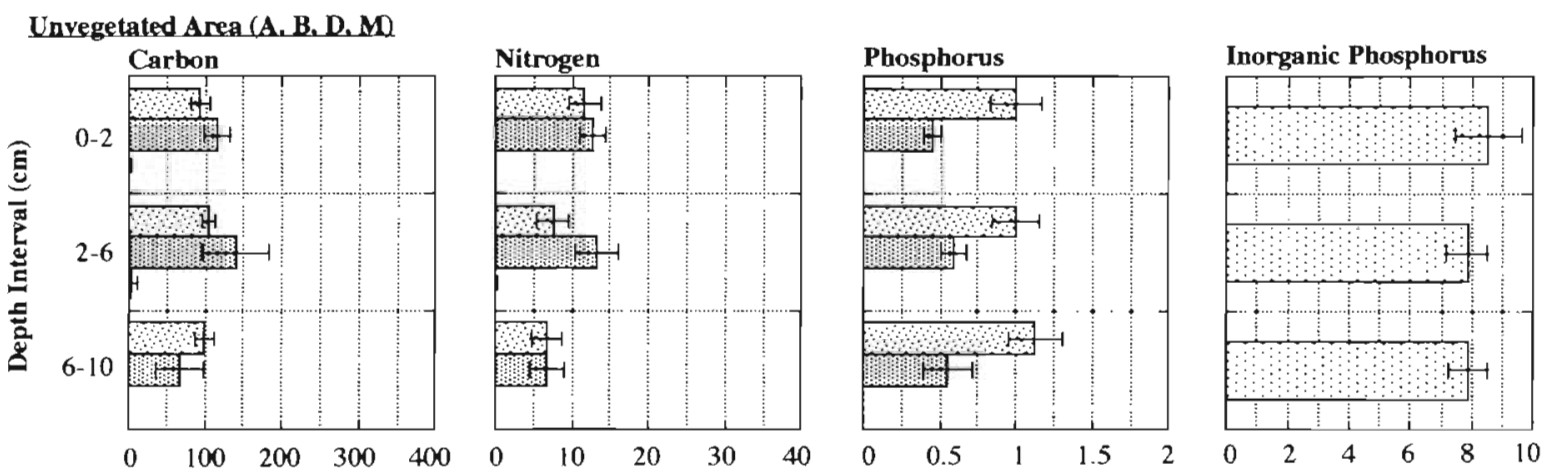

Seagrass Beds (C, E, F)
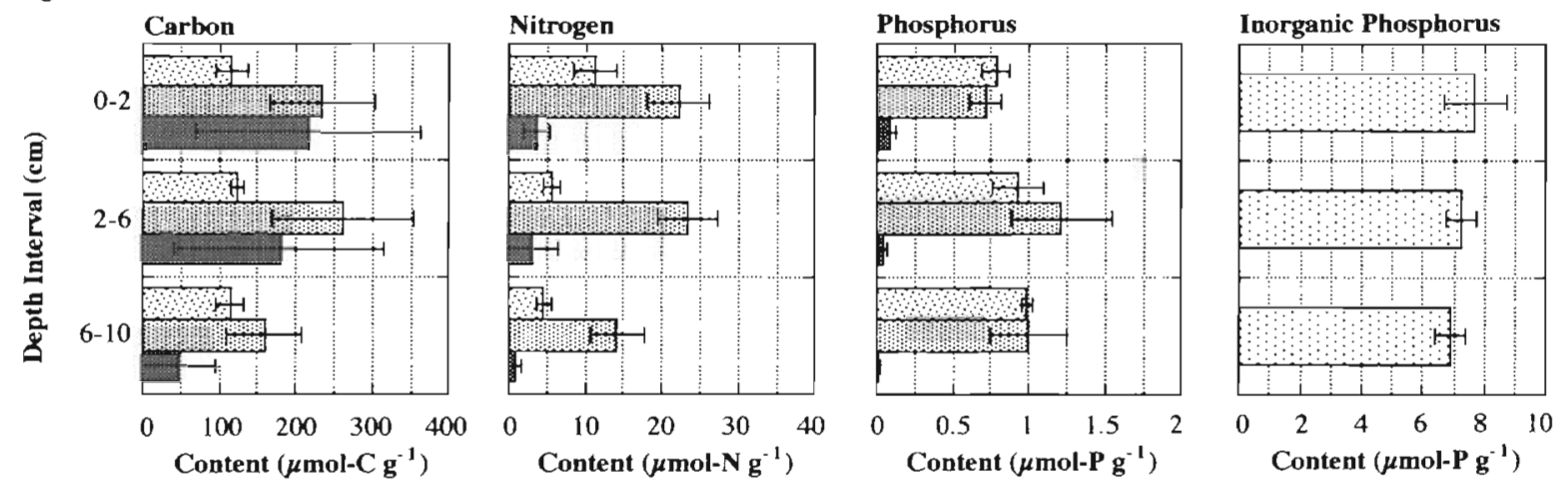

Fig. 2. Distribution of organic carbon, total nitrogen, organic phosphorus and inorganic phosphorus in sediment cores collected at 7 stations inside $(C, E, F)$ and outside $(A, B, D, M)$ seagrass beds at Green Island. For carbon, nitrogen and phosphorus the macroscopic detrital (Wraction-D), acid-insoluble amorphous (7., Fraction-I) and acid-soluble (B. Fraction-S) fractions of the sediment are shown (see text). For inorganic phosphorus only the acid-soluble fraction is shown. Error bars show \pm SD ( $\mathrm{n}=8$ for unvegetated area, $\mathrm{n}=6$ for seagrass beds)

to dissolve carbonate and acid-soluble phosphorus. The solution was well homogenized and passed through an acid-washed GF/F filter $(25 \mathrm{~mm}$ ). Each filter was placed on the bottom of a $30 \mathrm{ml}$ glass vial, dried at $40^{\circ} \mathrm{C}$, wetted with $400 \mu \mathrm{l}$ of $50 \%$ (w/v) $\mathrm{Mg}\left(\mathrm{NO}_{3}\right)_{2}$ solution, and dried again. The vial was then sealed with aluminum foil and baked at $550^{\circ} \mathrm{C}$ for $3 \mathrm{~h}$. After cooling, residue in the vial was dissolved with $10.0 \mathrm{ml}$ of $1.2 \mathrm{~N} \mathrm{HCl}$ at $100^{\circ} \mathrm{C}$ for $1 \mathrm{~h}$, and the supernatant was analyzed for reactive phosphate concentration. This fraction was regarded as acid-insoluble organic phosphorus in sediment (Fraction-I). The filtrate was analyzed for reactive phosphate and total dissolved phosphorus (from which dissolved organic phosphorus concentration was calculated) as described above. The dissolved reactive and organic fractions thus obtained were regarded as total inorganic and acid-soluble organic fractions of phosphorus in sediment (the latter being referred to as Fraction-S). Phosphorus in plant debris (Fraction-D) and sediment-trap samples was similarly analyzed, but the acid-soluble and insoluble organic fractions were collectively referred to as organic phosphorus.

\section{RESULTS}

Sediment from Green Island reef consisted of purely coralline and foraminiferous carbonate sand and was virtually devoid of terrigenous particles such as silt and clay. Organic carbon content in sediments of seagrass beds was clearly higher than in sediments of unvegetated areas (Fig. 2, Table 1). In the unvegetated area, sediment of Stn A was more depleted in organic carbon $\left(<200 \mu \mathrm{mol} \mathrm{g}{ }^{-1}\right)$ than sediments of downstream stations $\left(B, D, M ;>200 \mu m o l g^{-1}\right.$ except for the 6 to $10 \mathrm{~cm}$ layer). No significant difference was detected in sediment organic carbon content between seagrassbed stations (C, E, F). Abundant macroscopic plant debris was found in seagrass-bed sediments. Contribution of this macroscopic debris fraction (Fraction-D) to sediment organic carbon was most conspicuous at Stn C (up to $49 \%$ for the 2 to $6 \mathrm{~cm}$ layer). The debrisfree fraction of the sediment was partitioned into acidsoluble (Fraction-S) and insoluble (Fraction-I) subfractions. Nitrogen of Fraction-D and Fraction-I was essentially organic, while that of Fraction-S included 12 to $29 \%$ of $\mathrm{N}$ as inorganic forms (mainly $\mathrm{NH}_{4}{ }^{+} ; 7$ ran- 
Table 1. Difference in chemical composition of sediment between seagrass beds and unvegetated areas (average $\pm \mathrm{SE}_{i} \mu \mathrm{mol} \mathrm{g}{ }^{1}$ for solid fractions, $\mu \mathrm{M}$ for interstitial water nutrients). DIN: dissolved inorganic nitrogen; DIP: dissolved inorganic phosphorus. $\mathrm{n}=$ number of samples analyzed. $\mathrm{p}$-values from ANOVA.

\begin{tabular}{|c|c|c|c|}
\hline & $\begin{array}{l}\text { Unvegetated area } \\
\qquad(\mathrm{n}=24)\end{array}$ & $\begin{array}{l}\text { Seagrass bed } \\
\quad(n=18)\end{array}$ & $\mathrm{p}$ \\
\hline \multicolumn{4}{|c|}{ Acid-soluble organic (Fraction-S) } \\
\hline Carbon & $98.9 \pm 2.4$ & $118.1 \pm 3.9$ & 0.0003 \\
\hline Nitrogen & $8.59 \pm 0.60$ & $7.13 \pm 0.81$ & 0.5021 \\
\hline Phosphorus & $1.04 \pm 0.04$ & $0.90 \pm 0.03$ & 0.0062 \\
\hline \multicolumn{4}{|c|}{ Acid-insoluble, amorphous organic (Fraction-1) } \\
\hline Carbon & $107.5 \pm 8.9$ & $218.2 \pm 19.2$ & $<0.0001$ \\
\hline Nitrogen & $10.81 \pm 0.75$ & $19.86 \pm 1.31$ & $<0.0001$ \\
\hline Phosphorus & $0.53 \pm 0.03$ & $0.97 \pm 0.07$ & $<0.0001$ \\
\hline \multicolumn{4}{|c|}{ Macroscopic detrital (Fraction-D) } \\
\hline Carbon & $1.2 \pm 1.0$ & $148.3 \pm 31.6$ & $<0.0001$ \\
\hline Nitrogen & $0.02 \pm 0.02$ & $2.62 \pm 0.57$ & $<0.0001$ \\
\hline Phosphorus & $0.000 \pm 0.000$ & $0.046 \pm 0.009$ & $<0.0001$ \\
\hline Inorganic phosphorus & $8.09 \pm 0.17$ & $7.27 \pm 0.18$ & 0.0022 \\
\hline \multicolumn{4}{|l|}{ Interstitial water } \\
\hline DIN & $12.7 \pm 3.5$ & $73.9 \pm 10.0$ & $<0.0001$ \\
\hline DIP & $1.18 \pm 0.13$ & $2.70 \pm 0.30$ & $<0.0001$ \\
\hline
\end{tabular}

of Fraction-S $(133 \pm 21$ for seagrass beds, $96 \pm 11$ for unvegetated areas) was lower and less variable than that of Fraction-I $(236 \pm 84$ for seagrass beds, $204 \pm 70$ for unvegetated areas), and the C:P ratio of Fraction-I was generally lower in deeper layers.

Dissolved inorganic nitrogen (DIN) and phosphorus (DIP) in sediment pore water were higher in seagrassvegetated areas (especially Stn C) than in unvegetated areas (Fig. 3). Ammonium was the major component of the pore-water DIN, accounting for $>75 \%$ in unvegetated areas and $>98 \%$ in seagrass beds. Nitrate $\left(\mathrm{NO}_{3}{ }^{-}\right)$ and nitrite $\left(\mathrm{NO}_{2}{ }^{-}\right)$were always $<2.0 \mu \mathrm{M}$ and $<0.5 \mu \mathrm{M}$, respectively.

Concentrations of DIN, particulate organic nitrogen (PON) and dissolved organic nitrogen (DON) in overlying sea water collected at the same stations were $0.37-0.56,1.11-1.72$, and 13.05-15.90 $\mathrm{mmol} \mathrm{N} \mathrm{I}^{-1}$, respectively,

domly chosen samples were tested). This $\mathrm{NH}_{4}^{+}$is thought to be derived from pore water and adsorbed onto carbonate surfaces. In the case of phosphorus, about $80 \%$ of total sediment $\mathrm{P}$ was found in the inorganic fraction, which was presumably phosphate included in or adsorbed onto the surface of carbonate minerals (Kitano et al. 1978, Ishikawa \& Ichikuni 1981). about 10 to $15 \%$ of inorganic phosphorus could be extracted by alkaline solution $\left(0.5 \mathrm{M} \mathrm{Na}_{2} \mathrm{CO}_{3}\right.$; tested for 3 randomly chosen samples), which may be ascribed to the phosphate loosely adsorbed onto carbonate minerals.

Contents of organic carbon, nitrogen, and phosphorus in Fraction-I were significantly higher in the seagrass-bed sediments, especially at Stns E and F, than in the unvegetated sediments (Table 1); in contrast, there was relatively small variation among stations in organic carbon content in Fraction-S. However, the major reason for organic carbon enrichment in the seagrass-bed sediment was the presence of Fraction-D. which had extremely high C:N $(54.7 \pm 7.4)$ and $C: P$ $(3480 \pm 1120)$ atomic ratios. In most cases, the $C: N$ ratio of Fraction-S (19.5 \pm 7.7 for seagrass beds, $12.8 \pm 4.6$ for unvegetated areas) was higher and more variable than that of Fraction-I $(10.9 \pm 1.3$ for seagrass beds, $9.9 \pm 1.4$ for unvegetated areas), and the $\mathrm{C}: \mathrm{N}$ ratio of Fraction-S was generally higher in deeper layers. It should be noted that, as 12 to $29 \%$ of $\mathrm{N}$ in Fraction-S was inorganic, correct $\mathrm{C}: \mathrm{N}$ ratios for the acid-soluble organic fraction would be 14 to $40 \%$ higher, making the difference from Fraction-I greater. In contrast, the C:P ratio with 86 to $91 \%$ of total $N$ present in the form of DON. Similarly, concentrations of DIP, particulate phospho-

\section{DN in pore water}
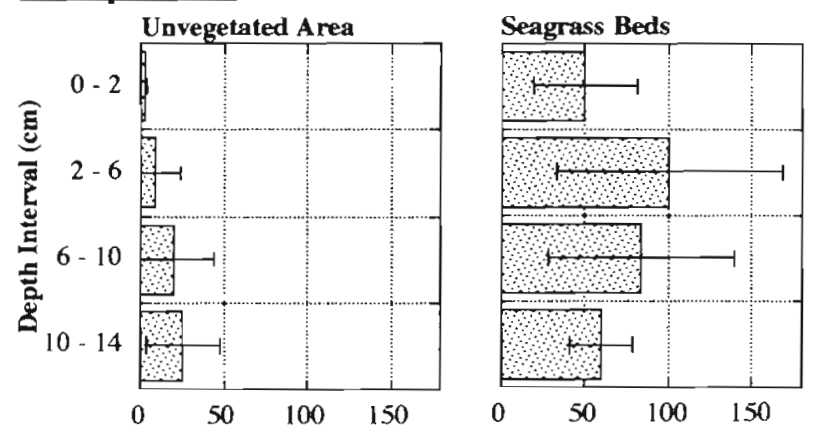

DIP in pore water
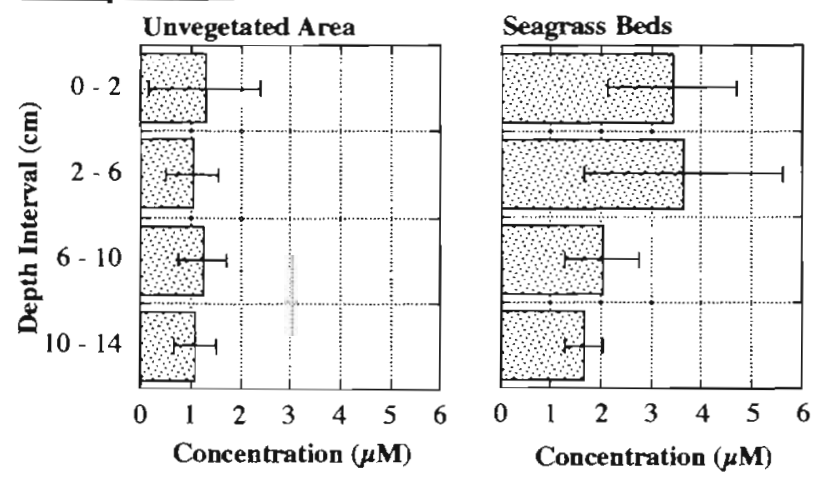

Fig. 3. Concentrations of dissolved inorganic nitrogen (DIN) and phosphorus (DIP) in sediment pore water. Sampling stations as in Fig. 2. Error bars show $\pm \mathrm{SD}$ 

flat stations. POC: particulate organic carbon; PON: particulate organic nitrogen PP: particulate phosphorus

\begin{tabular}{|lccccccc|}
\hline & \multirow{2}{*}{ Off-reef } & \multicolumn{7}{c|}{ Reef-flat } \\
\cline { 3 - 7 } & & A & B & C & D & E & F \\
\hline POC $\left(\mu \mathrm{mol} \mathrm{l}{ }^{-1}\right)$ & 5.86 & 8.89 & 9.73 & 10.8 & 11.2 & 16.6 & 14.2 \\
POC:PON $\left(\mathrm{mol} \mathrm{mol}^{-1}\right)$ & 7.6 & 6.8 & 8.8 & 8.8 & 8.8 & 9.9 & 8.3 \\
POC:PP $\left(\mathrm{mol} \mathrm{mol}^{-1}\right)$ & 90 & 81 & 117 & 130 & 165 & 147 & 116 \\
POC:chl $a\left(\mathrm{Mg}^{-1}\right)$ & 98 & 240 & 288 & 519 & 826 & 722 & 730 \\
\hline
\end{tabular}

Table 2. Distribution of particulate matter in sea water at 1 off-reef and 6 reef-

sediment trapped in vegetated areas (Table 3). Organic carbon content in trapped sediment was higher than in average surface sediment, especially in seagrass-vegetated areas. It was generally low for the sediment trapped on windy days ( $p=0.0094$ ), which was consistent with a visual observation that the trap samples obtained on windy days (especially at Stns A and B) consisted predominantly of carbonate sand grains, in rus (PP) and dissolved organic phosphorus (DOP) in sea water were $0.07-0.10,0.07-0.12$, and

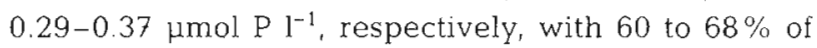
total phosphorus present in the form of DOP. Concentrations of DIN and DIP were higher in the pore water of surface sediment than in overlying sea water; in particular, the concentration gradients of $\mathrm{NH}_{4}{ }^{+}$and DIP across the sediment/water boundary of seagrass beds were very large. Concentration of particulate organic carbon increased downstream (Table 2). Organic carbon content per unit weight of chl a in POM increased from 240 to $>700$ downstream. A similar trend was also observed for surface sediment (from 300 to 2400, data not shown). This suggests that chlorophyll-depleted detrital POM as opposed to living phytoplankton became predominant downstream in both POM and sediment organic matter.

Transport of sediment particles by water current was estimated by sediment traps that were put directly on the bottom at 6 stations $(\mathrm{A}-\mathrm{F})$. The experiment was repeated 4 times (first: October 20-21; second: October 22-23; third: October 24-25; fourth: October 27-28). Visual observation of trapped material revealed that it consisted of fine carbonate sand grains as the major component, with various fraction of dark-colored organic particles. The amount of trapped sediment is shown in Fig. 4 as organic carbon collected $\mathrm{cm}^{-2} \mathrm{~d}^{-1}$ The first and fourth experiments were conducted under relatively calm weather conditions (wind speed 5.7 to $8.7 \mathrm{~m} \mathrm{~s}^{-1} ; 3 \mathrm{~h}$ average data from Green Island Automatic Weather Station, courtesy of Australian Bureau of Meteorology, Brisbane), whereas the second and third experiments were done on windy days (8.2 to $13.9 \mathrm{~m} \mathrm{~s}^{-1}$ ). The amount of organic carbon trapped per day strongly depended on the wind condition (ANOVA: $p=0.0006$ ) but not on vegetation ( $p=0.5483$ ). Organic carbon content per unit weight of the trapped sediment was higher in the contrast to those obtained on calm days which consisted mainly of organic detrital material.

Organic C:N and C:P ratios were compared among POM suspended in sea water, trapped sediment, and 3 fractions of bulk sediment in unvegetated areas and seagrass beds (Table 4). For C:N they were ordered as $\mathrm{POM} \leq$ trap $=$ Fraction $-\mathrm{I}<$ Fraction $-\mathrm{S} \ll$ Fraction $-\mathrm{D}$; for $\mathrm{C}: \mathrm{P}$ they were ordered as $\mathrm{POM} \approx$ Fraction-S $<$ FractionI $\leq$ trap $\ll$ Fraction-D.

In both unvegetated areas and seagrass beds, the organic C:N ratio of sediment trap samples was statistically indistinguishable from that of Fraction-I of bulk sediment, while significantly lower than that of Fraction-S and Fraction-D (Table 4). The C:P ratio of the trapped sediment was similar to that of Fraction-I in unvegetated area, while different in seagrass beds.

\section{DISCUSSION}

The amount of organic carbon contained in the carbonate skeletons of calcareous organisms is quite small, typically $<200 \mu \mathrm{mol} \mathrm{g}{ }^{-1}$ (Johnston 1980, Barnes $\&$ Chalker 1990). From the view of the chemistry of carbonate sediment, this matrix fraction represents the background level of organic carbon content in the car-

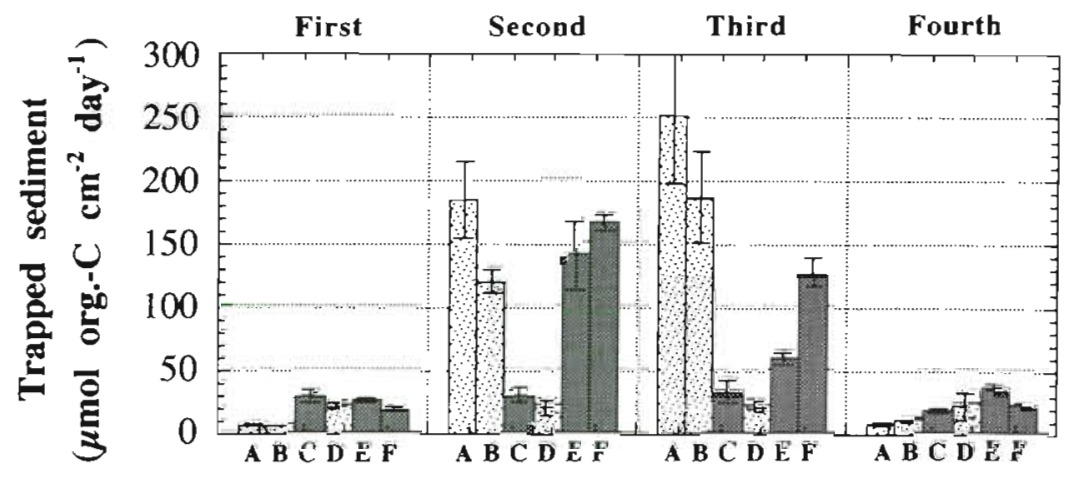

Fig. 4. Amounts of particulate organic carbon collected by sediment traps at 6 stations (A-F). Samples taken from unvegetated areas (1) and seagrass beds

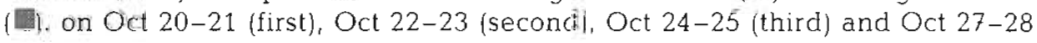
(fourth). Error bars show \pm SD for triplicate bottles 
mann 1973, Coffroth 1990) and plankton, or aged detrital particles resuspended from sediment. However, the amount of organic particles collected by sediment traps markedly differed between calm and windy days, which suggests that the majority of the trapped particles originated from sediment resuspension. The C:N:P ratio of the organic fraction of the trapped particles was similar to that of Fraction-I. Further, the observation that the POC:chl a weight ratio in the sea water overlying the reef flat ranged from 240 to 830 , as opposed to $<100$ in the off-reef water, implies that the resuspended aged detritus also represented the major fraction of suspended particulate matter. The organic carbon:chl a ratio of surface sediment was also high $(300-2400)$. It is thus feasible that fine detrital matter represented by Fraction-I was the major source of the trapped organic particles (and perhaps POM) over the seagrass beds.

Resuspended organic particles can be transported by water current that continuously flows in a roughly fixed direction. Hansen et al. (1992) reported that a significant fraction of the products of reef-flat primary production could be transported as particulate material and reach lagoon sediments at Davies Reef, Great Barrier Reef. Thus, resuspension and transport of sediment organic matter may be a significant path of $C, N$ and $P$ from upstream to downstream compartments of a reef system.

To roughly estimate the relative impact of the physical transport of sediment organic matter by resuspension and water current in the reef flat, we simply assume that trapped organic matter was derived from resuspension of Fraction-I and that the upper $10 \mathrm{~cm}$ layer of sediment was subjected to resuspension. In the seagrass-bed area, organic carbon collected per day by sediment traps on calm and windy days amounted to 0.6 to $1.5 \%$ and 1.7 to $5.9 \%$, respectively, of the organic carbon standing stock of Fraction-I in the upper $10 \mathrm{~cm}$ of sediment; that is, the turnover time of Fraction-I organic carbon due to resuspension would be 17 to $170 \mathrm{~d}$ under the above assumptions. The turnover time of organic nitrogen and phosphorus should be roughly same as carbon, because the $\mathrm{C}: \mathrm{N}: \mathrm{P}$ ratios of Fraction-I and trapped sediment were similar to each other. These calculations should be regarded as minimal estimates for turnover rates, since our sediment traps could capture only the resuspended sediment particles that had been lifted $>10 \mathrm{~cm}$ above the sediment surface. Further, the sediment layer subjected to resuspension would actually be thinner, probably $<1 \mathrm{~cm}$ on calm days. Thus it is possible that the organic matter in the top few cm would be more mobile, with a turnover time of the order of $10 \mathrm{~d}$, while that in deeper sediments would be more stable.
Knowledge on the mineralization rate of sediment organic matter is crucial for appreciation of the impact of physical sediment transport on material cycling; if the characteristic time scale for mineralization is considerably shorter than that of physical transport, the latter could have only a marginal role in redistribution of the products of reef-flat primary production. However, information about mineralization rate in reef-flat sediment is very sparse. The turnover times of porewater nutrients in reef-flat sediments have been reported to be of the order of $1 \mathrm{~d}$ for $\mathrm{NH}_{4}^{+}$(Boon 1986 , Capone et al. 1992, Blackburn et al. 1994) and several days for $\mathrm{PO}_{4}^{3-}$ (Moriarty \& Boon 1989). The standing stocks of sediment organic nitrogen and phosphorus are usually more than 2 orders of magnitude larger than the pore-water ammonium and phosphate. The turnover times of organic $\mathrm{N}$ and $\mathrm{P}$ due to mineralization would be proportionally longer than those of porewater fractions, i.e. $10^{2} \mathrm{~d}$ or longer, if the pore-water ammonium and phosphate are the principal mineralization products in the sediment. This idea may be supported by laboratory decomposition experiments of seagrass leaves which showed that, although initial loss of labile organic carbon was rapid, resistant fiber fractions (including microbial biomass) survived for many weeks (Blum \& Mills 1991, Peduzzi \& Herndl 1991, Opsahl \& Benner 1993). Thus, at the first approximation, the characteristic time scales of sediment organic $\mathrm{N}$ and $\mathrm{P}$ turnover by physical resuspension are similar to or shorter than that of mineralization. It is thus feasible that, at least for relatively refractory fractions derived from seagrasses, sediment organic matter is transported by resuspension and water current without significant mineralization. Hence, physical sediment transport may be one of the most important agents that determine distribution and turnover of the products of reef-flat primary production.

Acknowledgements. We gratefully acknowledge Warren Lee Long. Chanlal Roder and other staff of Queensland Department of Primary Industry who provided us with technical assistance in field work, research facilities, and useful information about Green Island reef. This study was financially supported by the Japan Society for Promotion of Science (JSPS). H.Y. was supported by the JSPS scholarship program. T.M. and I.K. are cooperative researchers for the Japan Science and Technology Corporation.

\section{LITERATURE CITED}

Almasi MN, Hoskin CM, Reed JK, Milo J (1987) Effects of natural and artificial Thalassia on rates of sedimentation. J Sediment Petrol 57:901-906

Atkinson MJ, Smith SV (1983) C:N:P ratios of benthic marine plants. Limnol Oceanogr 28:568-574

Barnes DJ, Chalker BE (1990) Calcification and photosynthesis in reef-building corals and algae. In: Dubinsky $Z$ (ed) 
Coral reefs. Elsevier Science Publishers BV, Amsterdam, p 109-131

Blackburn TH, Nedwell DB, Wiebe WJ (1994) Active mineral cycling in a Jamaican seagrass sediment. Mar Ecol Prog Ser 1 10:233-239

Blum LK, Mills AL (1991) Microbial growth and activity during the initial stages of seagrass decomposition. Mar Ecol Prog Ser 70:73-82

Boon PI (1986) Uptake and release of nitrogen compounds in coral reef and seagrass, Thalassia hemprichii (Ehrenb) Aschers, bed sediments at Lizard Island, Queensland. Aust J Mar Freshw Res 37:11-19

Capone DG, Dunham SE, Horrigan SG, Duguay LE (1992) Microbial nitrogen transformations in unconsolidated coral reef sediments. Mar Ecol Prog Ser 80:75-88

Carter PW (1978) Adsorption of amino acid-containing organic matter by calcite and quartz. Geochim Cosmochim Acta 42:1239-1242

Coffroth. MA (1990) Mucous sheet formation on poritid corals: an evaluation of coral mucus as a nutrient source on reefs. Mar Biol 105:39-49

Coles SL, Strathmann R (1973) Observations on coral mucus 'flocs' and their potential trophic significance. Limnol Oceanogr 18:673-678

Dauby P, Bale AJ, Bloomer N, Canon C, Ling RD, Norro A, Robertson JE, Simon A, Theate JM, Watson AJ, Frankignoulle $M$ (1995) Particle fluxes over a Mediterranean seagrass bed: a one year case study. Mar Ecol Prog Ser 126: 233-246

Erftemeijer PLA (1994) Differences in nutrient concentrations and resources between seagrass communities on carbonate and terrigenous sediments in south Sulawesi, Indonesia. Bull Mar Sci 54:403-419

Fonseca MS (1989) Sediment stabilization by Halophila decipiens in comparison to other seagrasses. Estuar Coast Shelf Sci 29:501-507

Fonseca MS, Cahalan JA (1992) A preliminary evaluation of wave attenuation by four species of seagrass. Estuar Coast Shelf Sci 35:565-576

Fonseca MS, Fisher JS (1986) A comparison of canopy friction and sediment movement between four species of seagrasses with reference to their ecology and restoration. Mar Ecol Prog Ser 29:15-22

Grasshoff K (1976) Methods of seawater analysis. Verlag Chemie, Weinheim

Hansen JA, Klumpp DW, Alongi DM, Dayton PK, Riddle MJ (1992) Detrital pathways in a coral reef lagoon II. Detritus deposition, benthic microbial biomass and production. Mar Biol 113:363-372

Harrison PG, Mann KH (1975) Detritus formation from ee]grass (Zostera marina L.): the relative effects of fragmentation, leaching, and decay. Limnol Oceanogr 20:924-934

Hatcher BG, Imberger J, Smith SV (1987) Scaling analysis of coral reef systems: an approach to problems of scale. Coral

Editorial responsibility: Otto Kinne (Editor),

Oldendorf/Luhe, Germany
Reefs 5:171-181

Hedges JI, Stern JH (1984) Carbon and nitrogen determinations of carbonate-containing solids. Limnol Oceanogr 29 : $657-663$

Ishikawa M. Ichikuni M (1981) Coprecipitation of phosphate with calcite. Geochem J 15:283-288

Johnston is (1980) The ultrastructure of skeletogenesis in hermatypic corals. Int Rev Cytol 67:171-214

Kitano Y, Okumura M, ldogaki M (1978) Uptake of phosphate ions by calcium carbonate. Geochem J 12:29-37

Klug MJ (1980) Detritus-decomposition relationships. In: Phillips RC, McRoy CP (eds) Handbook of seagrass biology. Garland STPM Press, New York, p 225-245

Moriarty DJW, Boon PI (1989) Interactions of seagrasses with sediment and water. In: Larkum AWD, McComb AJ, Shepherd SA (eds) Biology of seagrasses: a treatise on the biology of seagrasses with special reference to the Australian region. Elsevier, Amsterdam, p 500-535

Morse JW, Zullig JJ, Iverson RL, Choppin GR, Mucci A, Millero FJ (1987) The influence of seagrass beds on carbonate sediments in the Bahamas. Mar Chem 22:71-83

Mukai H (1993) Biogeography of the tropical seagrasses in the Western Pacific. Aust J Mar Freshw Res 44:1-17

Opsahl S, Benner R (1993) Decomposition of senescent blades of the seagrass Halodule wrightii in a subtropical lagoon. Mar Ecol Prog Ser 94:191-205

Peduzzi P, Herndl GJ (1991) Decomposition and significance of seagrass leaf litter (Cymodocea nodosa) for the microbial food web in coastal waters (Gulf of Trieste, Northern Adriatic Sea). Mar Ecol Prog Ser 71:163-174

Scoffin TP (1970) The trapping and binding of subtidal carbonate sediments by marine vegetation in Bimini lagoon, Bahamas. J Sediment Petrol 40:249-273

Suess $E$ (1973) Interaction of organic compounds with calcium carbonate-II. Organo-carbonate association in recent sediments. Geochim Cosmochim Acta 37:2435-2447

Thomassin BA, Cauwet G (1985) Organic matter distribution in sediments of the Tulear coral reef complexes. In: Proc 5th Int Coral Reef Congress, Tahiti 1:77-382

Tribble GW, Sansone FJ, Smith SV (1990) Stoichiometric modeling of carbon diagenesis within a coral reef framework. Geochim Cosmochim Acta 54:2439-2449

Wanless HR (1981) Fining-upwards sedimentary sequences generated in seagrass beds. J Sediment Petrol 51:445-454

Ward LG, Kemp WM, Boynton WR (1984) The influence of waves and seagrass communities on suspended particulates in an estuarine embayment. Mar Geol 59:85-103

Williams SL, Gill IP, Yarish SM (1985) Nitrogen cycling in backreef sediments (St Croix, US Virgin Islands). In: Proc 5th Int Coral Reef Congress, Tahiti 1:389-394

Yamamuro M, Koike I, lizumi $H$ (1993) Partitioning of the nitrogen stock in the vicinity of a Fijian seagrass bed dominated by Syringodium isoetifolium (Ascherson) Dandy. Aust J Mar Freshw Res 44:101-115

Submitted: June 3, 1998; Accepted: September 8, 1998 Proofs received from author(s): November 30, 1998 